\title{
Optimalisasi Macromedia Flash Untuk Mendukung Pembelajaran Berbasis Komputer Pada Program Studi Ilmu Komputer
}

\author{
VIVI ERYANI \\ 175100014 \\ Universitas Mitra Indonesia, Sistem Informasi \\ Vivieryani.student@umitra.ac.id
}

\begin{abstract}
ABSTRAK
Pembelajaran dengan menggunakan animasi komputer memberikan kesempatan kepada peseta didik untuk belajar secara dinamis dan interaktif. Salah satu penilaian yang digunakan dalam lingkungan software pembelajaran adalah penilaian performent pembelajar. Walaupun prinsip-prinsip penilaian performent pembelajar tidak berubah ketika diterapkan dengan software pembelajaran, tetapi lingkungan pembelajaran terdapat perbedaan yang cukup signifikan dari model pembelajaran konvensional. Lingkungan software pembelajaran menciptakan penilaian yang lebih intensif, yaitu disaat teknologi meningkatkan efisiensi penilaian dalam lingkungan software pembelajaran. Banyak keuntungan diperoleh dari penggunaan media komputer sebagai alat bantu pembelajaran.

Komputer (mikro) dapat merupakan media pengajaran yang dapat memvisualisasikan berbagai fakta, keterampilan, konsep dan komputer juga menampilkan gambar-gambar yang bergerak sesuai dengan keperluannya. Penggunaan komputer yang bersifat interaktif dengan pemakainya bahwa program komputer yang dapat menampilkan diagram atau gambar dapat dirancang untuk menyesuaikan dengan respon pembelajar. Selain itu, penggunaan komputer dapat dirancang sedemikian sehingga dapat berinteraksi dengan pemakainya. Komputer selain dapat menciptakan iklim belajar yang efektif bagi mahasiswa yang lambat (slow learner), tetapi juga dapat memacu efektivitas belajar bagi mahasiswa yang lebih cepat (fast learner).
\end{abstract}

Kata kunci :Komputer, Software Macromedia Flash 


\section{A. PENDAHULUAN}

Pengembang media pembelajaran dan pemrograman, dapat memberikan kontribusi dalam hal penyediaan media berupa software-software yang dapat menunjang suatu pembelajaran. Bagi peseta didik terutama calon pendidik, perhatian dapat diarahkan pada upaya penyusunan program pembelajaran dengan menggunakan aplikasi program komputer. Pembelajaran dengan menggunakan animasi komputer memberikan kesempatan kepada peseta didik untuk belajar secara dinamis dan interaktif. Berangkat dari pemikiran tersebut, perlu dikembangkan pendidikan berbasis teknologi informasi dan komunikasi (ICT) dalam pembelajaran, yakni dengan membuat software pembelajaran multimedia interaktif. Pembuatan software pembelajaran mengacu pada aspek pedagogi materi subjek dengan harapan memberikan pemahaman yang mendasar kepada peseta didik terhadap materi subjek. Software pembelajaran multimedia interaktif dapat dikembang dengan menggunakan sebuah bahasa pemprograman dan disajikan dalam bentuk CD pembelajaran. Media pembelajaran adalah semua alat bantu atau benda yang digunakan dalam kegiatan belajar mengajar, dengan maksud untuk menyampaikan pesan pembelajaran dari sumber (guru maupun sumber lain) kepada penerima (dalam hal ini anak didik ataupun warga belajar). Pesan yang disampaikan melalui media, dalam bentuk isi atau materi pengajaran itu harus dapat diterima oleh penerima pesan (anak didik), dengan menggunakan salah satu ataupun gabungan beberapa alat indera mereka. Bahkan lebih baik lagi bila seluruh alat indera yang dimiliki mampu menerima isi pesan yang disampaikan. Komputer dalam perkembangan masa kini merupakan suatu peralatan yang canggih dan dapat dimanfaatkan diantaranya dalam masalah pendidikan dan pembelajaran. Dengan memanfaatkan kelebihan-kelebihan komputer, maka komputer dapat dijadikan sebagai media dan sumber belajar dalam bidang studi tertentu disamping media yang lain. Penggunaan komputer dalam pembelajaran di sekolah, dapat diklasifikasikan ke dalam beberapa jenis, yaitu:

1.Program latihan (drill and practice),yaitu program yang dirancang untuk digunakan pembelajar dalam melakukan latihanlatihan soal.

2.Program tutorial, yaitu program yang dirancang agar komputer dapat berlaku sebagai tutor dalam proses pembelajaran. 
3.Program demonstrasi, yaitu program yang digunakan untuk memvisualisasikan konsep yang abstrak.

4.Program simulasi, yaitu program yang digunakan untuk memvisualisasikan proses yang dinamik.

5.Program permainan instruksional, yaitu program yang digunakan untuk permainan dengan menggunakan instruksi-instruksi komputer dengan tujuan untuk meningkatkan pemahaman materi yang diajarkan.

Jika merujuk pada pengklasifikasian penggunaan komputer dalam pembelajaran di sekolah, maka model pembelajaran berbasis komputer ini mencakup program tutorial, program demonstrasi dan program simulasi.

\section{B. TINJAUAN PUSTAKA}

Dewasa ini Macromedia Flash telah menjadi primadona para designer web sebagai sarana untuk menciptakan sebuah situs web yang menarik dan interaktif.

\section{STUDY KASUS}

\subsection{Komputer Sebagai Alat Bantu Pembelajaran}

Banyak keuntungan diperoleh dari penggunaan media komputer sebagai alat bantu pembelajaran. Beberapa ahli menyatakan bahwa pengajaran yang menggunakan komputer dapat mengembangkan keterampilan berpikir. Selain itu penggunaan media komputer dapat menyeimbangkan kebutuhan waktu dan keperluan pemrosesan dari tugas-tugas tertentu, serta memungkinkan pengembangan pendekatan pembelajaran bervariasi Komputer (mikro) dapat merupakan media pengajaran yang dapat memvisualisasikan berbagai fakta, keterampilan, konsep dan komputer juga menampilkan gambar-gambar yang bergerak sesuai dengan keperluannya. Penggunaan komputer yang bersifat interaktif dengan pemakainya bahwa program komputer yang dapat menampilkan diagram atau gambar dapat dirancang untuk menyesuaikan dengan respon pembelajar. Selain itu, penggunaan komputer dapat dirancang sedemikian sehingga dapat berinteraksi dengan pemakainya. Komputer selain dapat menciptakan iklim belajar yang efektif bagi mahasiswa yang lambat (slow learner), tetapi juga dapat memacu efektivitas belajar bagi mahasiswa yang lebih cepat (fast learner). Sejalan dengan pendapat yang dikemukakan Heinich, kenyataan di lapangan memperlihatkan bahwa kecepatan pembelajar mempelajari suatu materi tidak hanya ditunjang oleh kemampuan kognisi pembelajar tetapi juga 
dipengaruhi oleh kemampuan pembelajar dalam mengoperasikan komputer. Ada beberapa kelemahan penggunaan komputer sebagai media pembelajaran. Tidak semua komputer dapat digunakan sebagai media pembelajaran, komputer harus menunjukkan kinerja yang baik ditinjau dari segi teknis dan spesifikasinya. Belajar dengan menggunakan media komputer menjadikan pembelajar aktif dalam belajar karena adanya pertanyaan-pertanyaan yang disertai dengan pernyataan penguatan. Motivasi pembelajar bertambah karena mereka lebih mudah mengikuti dan memahami materi yang diberikan. Beberapa kelebihan komputer antara lain:

a. Bekerja dengan komputer sebagai sesuatu yang baru bagi pembelajar, menimbulkan motivasi bagi mereka untuk lebih menekuni materi yang disajikan.

b. Dengan adanya warna, musik, dan grafik yang dianimasi dapat menambahkan realisme, dan merangsang untuk mengadakan latihan-latihan kerja, kegiatan laboratorium, simulasi dan sebagainya.

c. Kecepatannya dalam hal menanggapi respon pembelajar, justru merupakan sesuatu yang mengandung nilai-nilai penguatan (reinforcement). d. Kemampuannya untuk mengingat secara cepat dan tepat, memungkinkan perlakuan/pekerjaan pembelajar yang lalu dapat dicatat dengan baik, dan dapat digunakan untuk merencanakan langkahlangkah selanjutnya.

e. Andaikata komputer itu manusia, maka dapat digambarkan sebagai suatu pribadi yang sabar, sehinga dalam hal menggunakannya nampak suatu suasana tenang, aman, positif, dan tepat guna.

f. Kemampuan komputer dalam hal menyimpan dokumen secara aman, memungkinkan pengajaran individual dapat dijalankan dengan baik. Bagi

g. guru, persiapan-persiapan dapat dijalankan dengan baik untuk semua pembelajar (khususnya bagi pembelajar -pembelajar yang berbakat), dan kemajuan mereka dapat dimonitor.

h. Jangkauan kontrol guru lebih luas, dan banyak informasi dapat diperoleh; membantu guru mengadakan kontrol yang lebih ketat dan baik, tertuju pada bagianbagian yang secara langsung merupakan kesulitan bagi pembelajar .

Disamping beberapa keunggulan penggunaan komputer dalam 
pembelajaran, ternyata komputer mempunyai kelemahan-kelemahan dalam penggunaannya, yaitu:

1. Komputer tidak dapat membuat setiap hal jelas, seperti apa yang dikehendaki guru. Gagasan guru yang telah tersusun dalam perangkat pembelajaran belum tentu dapat diterima jelas oleh semua pembelajar . Komputer membantu guru dalam menjelaskan sebagian dari peran guru.

2. Komputer bukanlah alat bantu yang harus digunakan secara terus menerus, melainkan digunakan pada saat-saat tertentu dimana diperlukan oleh guru dan pembelajar. Penggunaan komputer dalam pengajaran dapat digunakan pada saat pembelajar memerlukan bantuan untuk meningkatkan prestasi belajarnya.

3. Komputer tidak dapat mengatasi permasalahan yang dihadapi secara individual dalam proses pembelajaran. Dan disinilah peran guru sangat penting untuk mengatasi permasalahan tersebut, sehingga komputer tidak mungkin menggantikan peran guru dalam proses pembelajaran, terutama pembelajar yang lambat daya tangkapnya terhadap informasi yang disampaikan.

4. Komputer tidak dapat menjangkau aspek afektif / sikap dari ranah pembelajaran sehingga komputer belum dapat digunakan mengubah tingkah laku pembelajar ke arah yang lebih baik.

5. Proses pembelajaran dengan komputer relatif lebih mahal dari media lain. Komputer memerlukan adanya pemikiran yang matang sebelum menggunakan komputer dalam pembelajaran; ditinjau dari segi biaya serta kegunaannya. Pemeliharaannya pun merupakan masalah yang perlu dipikirkan.

6. Merancang dan produksi program untuk kepentingan proses pembelajaran dengan komputer mempunyai konsekuensi biaya, waktu dan tenaga yang tidak sedikit.

7. Sering ada masalah yang tumpang tindih. Sering perangkat lunak (software) yang disiapkan untuk digunakan pada satu komputer tidak cocok untuk digunakan pada komputer lain.

Kelemahan-kelemahan penggunaan komputer dalam pembelajaran sebenarnya dapat diatasi walaupun tidak seluruhnya, jika program pembelajaran menggunakan komputer dibuat interaktif. Penerapan teknologi komputer mendorong proses pembelajaran ke arah "individual learning", di mana posisi guru bergeser 
dari instruktur tradisional ke arah mentor. Selain itu, pembelajaran individu mendorong pembelajar ke arah belajar aktif, kreatif dan interaktif. Dengan demikian maka perolehan pengetahuan pembelajar tidak lagi bersumber dari transfer ilmu oleh guru, melainkan melalui kegiatan membangun ilmu oleh pembelajar itu sendiri.

Tuntutan konstruktivisme saat ini dapat dipenuhi dengan baik oleh berbagai jenis software hypermedia interaktif yang berkembang saat ini. Dalam software ini, dengan mengklik suatu struktur menu/icon, pembelajar dapat dengan leluasa menelusuri, mencari, menemukan, membandingkan, mempertentangkan, menjawab soal (problem solving) dari materi pembelajaran yang mengintegrasikan teks, grafik animasi, simulasi, video dan suara yang dapat membuat pembelajar tertarik sebagai user. Dengan demikian akan terbangun suatu proses belajar yang interaktif sehingga sangat mungkin pembelajar dapat menemukan konsep, menciptakan pengertian dan pemahamannya serta membangun ilmunya sendiri melalui mentoring guru.

\subsection{Software Macromedia Flash}

Macromedia Flash adalah software yang dipakai luas oleh para profesional web karena kemampuannya yang mengagumkan dalam menampilkan multimedia, menggabungkan unsur teks, grafis, animasi, suara dan serta interaktivitas bagi pengguna program animasi internet. Dewasa ini Macromedia Flash telah menjadi primadona para designer web sebagai sarana untuk menciptakan sebuah situs web yang menarik dan interaktif. Macromedia Flash (Flash MX) merupakan sebuah program aplikasi standar authoring tool profesional yang digunakan untuk membuat animasi vektor dan bitmap yang sangat menakjubkan untuk keperluan pembuatan situs web yang interaktif dan dinamis. Selain itu, aplikasi ini juga dapat digunakan untuk membuat animasi logo, movie, game, pembuatan navigasi pada situs web, banner, tombol animasi, menu interaktif, interaktif form isian, e-card, screen saver dan pembuatan keseluruhan isi web atau pembuatan aplikasi-aplikasi web lain. Animasi dan gambar yang dibuat dengan flash akan tetap terlihat bagus pada ukuran windows dan resolusi layar berapapun. Hal ini disebabkan karena flash dibuat dengan teknologi vector graphic yang mendeskripsikan gambar memakai garis dan kurva, sehingga ukurannya dapat diubah sesuai kebutuhan tanpa mengurangi atau mempengaruhi kualitas dari gambar tersebut. Waktu loading (kecepatan 
gambar atau animasi yang muncul) lebih cepat dibanding dengan pengolahan animasi lainnya, seperti animated gifs dan java applet. Juga mampu membuat website yang interaktif, karena user dapat menggunakan keyboard atau mouse untuk berpindah ke bagian lain dari halaman web atau movie, memindahkan objek, memasukkan informasi di form. Mampu menganimasi grafis yang rumit dengan sangat cepat, sehingga membuat animasi layar penuh bisa langsung disambung ke situs web. Dapat diintegrasikan dengan server side scripting seperti CGI, ASP dan PHP untuk membuat aplikasi web database yang indah. Selain itu, dapat juga dipakai untuk membuat film pendek atau kartun, presentasi, iklan atau web banner, animasi logo, kontrol navigasi dan lain-lain. Flash $M X$ juga menyediakan kemampuan streaming video yang baru yang telah dikembangkan ke berbagai format video termasuk format MPG, DV (Digital Video), MOV (Quick time) dan AVI. Format-format video tersebut dapat disimpan ke dalam file flash $M X$ menggunakan kompresi file yang lebih baik. Dukungan video yang lebih luas tersebut memungkinkan kreativitas yang lebih baik dalam membuat movie flash. Kelebihan-kelebihan Macromedia
Flash MX dapat dimanfaatkan dalam dunia pendidikan guna tercapainya tujuan pembelajaran. Kelebihan ini telah digunakan dalam merancang program pembelajaran IPA berbasis komputer seperti kemampuannya menggabungkan kemampuan animasi huruf dan gambar yang menarik, animasi gambar dan huruf tetap terlihat bagus pada ukuran windows dan resolusi layar berapapun, kecepatan gambar, animasi atau huruf yang akan ditampilkan (muncul) dapat diatur kecepatannya serta dilengkapi dengan fasilitas tombol untuk dapat berpindah dari satu bagian ke bagian lainnya.

\section{DISKUSI}

Macromedia Flashs? Apa itu?

A. Macromedia Flash adalah software yang dipakai luas oleh para profesional web karena kemampuannya yang mengagumkan dalam menampilkan multimedia, menggabungkan unsur teks, grafis, animasi, suara dan serta interaktivitas bagi pengguna program animasi internet.

B. Animasi dan gambar yang dibuat dengan flash akan tetap terlihat bagus pada ukuran windows dan resolusi layar berapapun.

C. Dukungan video yang lebih luas memungkinkan kreativitas yang lebih baik dalam membuat movie flash. 


\section{E.KESIMPULAN}

Pembelajaran

dengan

menggunakan aplikasi komputer memberikan kesempatan kepada peserta didik untuk belajar secara dinamis dan interaktif. Bagi peserta didik terutama calon pendidik, perhatian dapat diarahkan pada upaya penyusunan program pembelajaran dengan menggunakan aplikasi program komputer. Berangkat dari pemikiran tersebut, perlu dikembangkan pendidikan berbasis teknologi informasi dan komunikasi (ICT) dalam pembelajaran, yakni dengan membuat software pembelajaran multimedia interaktif khususnya untuk beberapa mata kuliah yang memerlukan suatu alat peraga interaktif dalam kegiatan belajar mengajar seperti pada mata kuliah jaringan komputer ini.

Pembelajaran multimedia interaktif dapat dikembangkan dengan menggunakan suatu bahasa pemrograman dan disajikan dalam bentuk CD pembelajaran. Media pembelajaran adalah semua alat bantu atau benda yang digunakan dalam kegiatan belajar mengajar, dengan maksud untuk menyampaikan pesan pembelajaran dari sumber (guru maupun sumber lain) kepada penerima (dalam hal ini anak didik ataupun warga belajar). Pesan yang disampaikan melalui media, dalam bentuk isi atau materi pengajaran itu harus dapat diterima oleh penerima pesan (anak didik), dengan menggunakan salah satu ataupun gabungan beberapa alat indera mereka. Bahkan lebih baik lagi bila seluruh alat indera yang dimiliki mampu menerima isi pesan yang disampaikan. Metode seperti ini diharapkan dapat diterapkan dalam mata kuliah lain yang sejenis, yang memerlukan media pembelajaran dan alat peraga interaktif dalam kegiatan belajar mengajar.

\section{F. REFERENSI}

[1] PUTRA, Arie Setya; FEBRIANI, Ochi Marshella, Knowledge Management Online Aplication in PDAM Lampung Province. In: Prosiding International Conference On Information Technology and Business (ICITB).2018.P.181-187.

[2] FEBRIANI, Ochi Marshella; PUTRA,Arie Setya. Sistem Informasi Monitoring Inventori Barang Pada Balai Riset Standardisasi Industri Bandar Lampung. Jurnal Informatika,2014, 13:1:90-98

[3] PUTRA,A.S.(2018.July9). 2018 Artikel Struktur Data, Audit dan Jaringan Komputer, Retr1ievedfrom osf.io/3uq8w.

[4] Hariyanto, Bambang. 2000. Struktur Data. Bandung: CV. Informatika. Modul Dasar StrukturData"BSI". 
[5] Desphande P.S., O.G. Kakde (2004).C dan Data Structures. Charles River Media, Inc.Massachusetts. 